\title{
MENYOAL SIKAP GEREJA TERHADAP POLITIK
}

\author{
Markus Dominggus Lere Dawa
}

\begin{abstract}
Abstrak: Sikap gereja terhadap politik adalah isu yang masih terus relevan untuk didiskusikan di Indonesia. Setiap kali menjelang pemilu atau menyikap isu-isu tertentu dalam politik negara orang Kristen ramai meributkan sikap yang sebaiknya diambil gereja. Sikap yang banyak diambil adalah menjauhkan diri dari politik atau sekurang-kurangnya netral. Berangkat dari kasus sikap Sinode Gereja Kristus Tuhan (GKT) terhadap politik, tulisan ini hendak mendorong dilakukannya tinjau ulang terhadap sikap gereja terhadap politik. Dalam dialog dengan sejumlah pemikiran dari filsafat politik klasik dan pikiran sejumlah pemikir Kristen disimpulkan bahwa gereja sebaiknya lebih peduli dan aktif terlibat serta tidak menyerahkan urusan ini melulu kepada anggota-anggota gereja saja.
\end{abstract}

Kata-kata Kunci: GKT, politik, netralitas, pemerintah, tanggung jawab

\begin{abstract}
Apparently church and politics is still a debated issue in in Indonesia. It is even more debated around the time of national or regional general election. Out of contesting views, major view suggests that the church should hold at bay towards politics, refraining itself from supporting one or another competing parties, or at least holding a neutral position. Embarking on the position taken by Synod of the Church of Christ the Lord, this article wishes to encourage the church to review its synodical stance towards politics. Drawing form a number of thoughts on politics from classical philosophy of politics and from some Christian thinkers, it suggests that the church should put more concern and more actively involved in politics. While it is good to put this matter in the hand of its members, it is much better if the church, institutionally, do more than stay silent or neutral.
\end{abstract}

Key words: GKT, politics, neutrality, government, responsibility 


\section{PENDAHULUAN}

Saban kali menjelang kontes pemilihan umum, salah satu isu abadi yang dibicarakan oleh orang Kristen adalah bolehkah gereja berpolitik. Kalau dijawab "Ya" maka sejumlah pertanyaan segera muncul. Kalau boleh, lalu sampai sejauh mana? Sampai di mana batas yang dapat dicapai gereja dalam berpolitik sebelum ia berhenti menjadi gereja dan berubah menjadi partai politik? Apakah mengarahkan anggotanya untuk memilih seorang calon dan jangan memilih calon lain masih dapat dikatakan di dalam batas-batas itu? Ataukah lebih baik gereja hanya membicarakan himbauan umum agar mempergunakan hak pilih sebaikbaiknya dengan memilih calon-calon yang tepat, bebas korupsi dan berkomitmen kepada konstituen dan negara sementara dalam ketidaktahuannya akan orang-orang semacam itu anggota-anggota gereja akhirnya lebih banyak bergantung pada opini publik? Kalau dijawab "Tidak" lalu bagaimana sikap yang seharusnya diambil supaya gereja masih dapat dikatakan bertanggung jawab kepada Tuhan yang mengutusnya ke dunia untuk menjadi garam dan terang? Apakah hal itu cukup dengan melengkapi anggota-anggotanya dengan wawasan teologis Kristen tentang politik-sesuatu yang jika mau jujur jarang sekali dilakukan? Apakah hal itu cukup diserahkan kepada aktivitas individual anggota-anggotanya sementara sebagai perhimpunan gereja lebih baik "netral" saja? Bukankah semua orang tahu bahwa daya tawar politis perhimpunan orang jauh lebih kuat dari pada daya tawar individu?

Pertanyaan-pertanyaan semacam ini dan seribu satu macam pertanyaan lain yang berhubungan dengan keterlibatan pendeta atau rohaniwan/wati secara langsung dalam politik penulis temukan ketika ambil bagian dalam mengedukasi orang-orang Kristen di Malang dalam Pilpres 2014 yang lalu. Apa yang ditemukan di lapangan di antara orangorang Kristen itu, apakah itu pertanyaan dan juga harapan, menimbulkan pertanyaan: masih memadaikah posisi yang diambil sebagian besar gereja terhadap politik dalam menolong dirinya sendiri dan orang lain di negeri ini? Apakah sikap "netral" secara politik, dalam arti tidak mendukung si A atau si B, atau tidak mendukung Koalisi X atau Koalisi Y, masih merupakan cara bersaksi Kristen yang tepat? 
Tulisan ini tidak bermaksud memberikan jawaban yang komprehensif atas seluruh persoalan ini karena selain terbatasnya ruang juga dibutuhkan sebuah studi yang lebih mendalam dan komprehensif. Kondisi Indonesia yang maha luas dan keragaman dinamika lokal masing-masing juga memberi tantangan tersendiri untuk memberikan jawaban yang menyeluruh. Karena itu, penulis lebih suka meneropong persoalan ini dari sudut pengalaman Gereja Kristus Tuhan (GKT), yang penulis kenal selama ini. Inilah gereja yang pertama-tama penulis maksudkan ketika menyebut gereja dalam tulisan ini.

\section{SIKAP GKT TERHADAP POLITIK}

Sinode Gereja Kristus Tuhan (GKT) resmi berdiri pada tahun 1968 sebagai kelanjutan dari sebuah gereja untuk orang-orang Tionghoa Kristen yang lahir pada masa kolonial. Gereja tersebut adalah Tiong Hoa Kie Tok Kauw Hwee Klasis Jawa Timur (THKTKH Klasis Jatim). Gereja ini dirintis pada awal abad ke-20 oleh badan misi Gereja Methodist Konferensi Malaysia di kota Surabaya dengan anggota-anggota yang berlatar belakang pekerja migran dari negara Tiongkok. Menurut klasifikasi budaya zaman itu mereka disebut orang-orang Tionghoa singkheh dan totok, untuk membedakan mereka dari Tionghoa peranakan yang sudah lama bermukim di Hindia Belanda dan telah beradaptasi secara kultural dengan kebudayaan setempat. Dari segi politis mereka adalah orang-orang asing berkewarganegaraan Tiongkok.

Oleh pekerjaan seorang misionaris Belanda bernama H.A.C. Hildering kelompok Tionghoa totok ini kemudian dipersatukan dengan kelompok Tionghoa peranakan dalam sebuah gereja yang didirikan di kota Bangil pada tahun 1934, yang diberi nama Tiong Hoa Kie Tok Kauw Hwee (THKTKH) Oost Java. Gereja ini diakui resmi oleh Pemerintah Kolonial pada tahun 1939 dengan nama THKTKH Klasis Jatim. Istilah "klasis" diambil selain untuk menyiapkan sebuah kesatuan dengan gereja-gereja Tionghoa lain yang ada di Jawa Tengah dan Jawa Barat juga untuk menegaskan sifatnya sebagai suatu federasi gerejagereja. 
Pada pertengahan tahun 50-an, kelompok peranakan meninggalkan gereja ini dan membentuk sebuah gereja baru dengan bentuk sinode, yang diberi nama Gereja Kristen Indonesia Jawa Timur (GKI Jatim). Dalam gereja baru ini semua jemaat peranakan yang selama ini berbahasa Indonesia berkumpul menjadi satu. Pemisahan ini diterangkan sebagai respons terhadap perubahan kondisi internal dan eksternal gereja pasca kemerdekaan Indonesia di tahun 1945. Keputusan kelompok peranakan adalah "berorientasi kepada budaya bangsa Indonesia" dan "berorientasi kepada masyarakat Indonesia."1

Kelompok totok yang bertahan dalam THKTKH Klasis Jatim terus melanjutkan cara dan gaya bergereja yang sudah dikenalnya sejak dulu. Orientasi kultural dan politis hampir semua anggotanya masih tertuju kepada budaya dan masyarakat Tiongkok. Karakter budaya tetap totok, kewarganegaraan asing dan berbahasa Tionghoa dalam kehidupan gerejawi dan sehari-hari. Kondisi ini dipaksa berubah oleh keadaan setelah runtuhnya rezim Orde Lama pada tahun 1965. Walau sudah berkali-kali disarankan oleh DGI sejak awal tahun 60-an namun baru pada sidang raya DGI di Makassar pada tahun 1967, THKTKH Klasis Jatim akhirnya sedia melakukan perubahan. Langkah itu diwujudkan pada awal tahun 1968 dengan keputusan mengubah THKTKH Klasis Jatim menjadi Sinode Gereja Kristus Tuhan. Perubahan itu diikuti dengan penyesuaian-penyesuaian di segala bidang supaya GKT benar-benar cocok dengan situasi kegerejaan Indonesia pasca 65. Anggota-anggota gereja yang dahulunya warga negara asing (WNA) kini berbondongbondong menjadi warga negara Indonesia (WNI) dan mengikuti seluruh kebijakan yang ditetapkan pemerintah Orde Baru untuk orang Tionghoa.

Meski sedang berada dalam suasana politik yang sedang berubah sangat cepat, pada waktu itu GKT belum berpikir untuk menyediakan suatu aturan yang akan membimbing laku anggota-anggotanya di bidang politik. Pedoman itu baru dibuat setahun kemudian di dalam sidang

1 Lihat artikel "Selayang Pandang Kehidupan Oikumenis GKI Jatim" dalam Buku Kenang-kenangan 50th Gereja Kristen Indonesia Jawa Timur, 22-2-1934-22-2-1984 (Malang: Panitia HUT Ke-50 Gereja Kristen Indonesia Jawa Timur, 1984), tanpa halaman 
sinode GKT yang kedua pada tahun 1969. Dalam keputusannya dinyatakan demikian, "Mengenai hubungan gereja dengan politik: Gereja harus patuh kepada Peraturan-peraturan Pemerintah, anggota jemaat hanya dapat mengikuti gerakan politik secara pribadi sebagai warga negara dan dilarang menyangkut nama Gereja."”2

Di dalam keputusan ini GKT membedakan sikap yang diambil oleh gereja dari sikap yang dapat diambil oleh anggota-angota jemaatnya. Jemaat, menurut definisi Pasal VI Tata Gereja GKT, adalah perhimpunan orang-orang Kristen setempat dengan jumlah tertentu dan yang memiliki tempat beribadah serta kepengurusan yang tertentu. Tiap-tiap jemaat merupakan sebagian dari sebuah gereja yang satu dan sama yang bernama GKT. Sikap gereja secara keseluruhan, dan itu berarti sikap seluruh anggotanya, adalah patuh kepada peraturan pemerintah. Meski peraturan yang diberlakukan dapat terasa tidak adil, seperti dapat dijumpai pada peraturan-peraturan yang mengatur orang-orang Tionghoa, GKT menyatakan diri tetap tunduk dan memanggil semua anggotanya untuk patuh. Kepatuhan tanpa syarat ini disertai pula dengan izin bagi setiap anggotanya untuk mengikuti gerakan-gerakan dan partai-partai politik yang dipandang dapat menyalurkan aspirasi-aspirasi politik pribadinya. Namun demikian diingatkan supaya diciptakan jarak antara individu yang berpolitik dan gereja. Aktivitas politik itu murni pribadi dan tidak ada sangkut pautnya sama sekali dengan gereja. Gereja tidak boleh menjadi alat politik sekaligus tidak boleh menjadi tempat di mana anggota jemaat menjalankan aktivitas politiknya. Bendera gereja tidak boleh dikibarkan bersama-sama dengan bendera gerakan politiknya. Gereja harus menjadi ruang sekaligus institusi yang steril dari anasiranasir politik individu-individu anggotanya.

Dalam situasi di mana dominasi negara atas kehidupan masyarakat begitu kuat seperti pada zaman Orde Baru, posisi yang diambil GKT ini sekurang-kurangnya memberi dua keuntungan. Yang pertama, di tengahtengah sikap negatif terhadap orang-orang Tionghoa negara tidak akan memperlakukan GKT sebagai lawan. Sikap GKT justru memperlihatkan

\footnotetext{
${ }^{2}$ Ringkasan Akta Sidang Lengkap Tahun 1969 Sinode Gereja Kristus Tuhan, Butir III.
} 
kesan bahwa GKT adalah pendukung sekaligus sekutu negara dan pemerintah. Yang kedua, dengan menyerahkan tanggung jawab dan risiko atas aktivitas politik anggota-anggotanya kepada diri mereka sendiri maka dibuat kecil kemungkinannya bagi anggota-anggota GKT untuk mengambil bagian secara terbuka dalam gerakan-gerakan politik yang berlawanan dengan posisi pemerintah. Tanpa basis dukungan dari komunitas keagamaan dan kultural di mana seorang individu berada maka sangat sukar bagi seorang GKT yang selama ini terkurung dalam "ghetto-nya" untuk masuk ke dunia politik dengan percaya diri.

Meski terasa tepat dan aman untuk situasi di mana orang-orang Tionghoa sedang mengalami tekanan dari segala penjuru namun posisi ini juga berpotensi menimbulkan konflik di dalam dirinya sendiri. Manakala anggota suatu jemaat memiliki aspirasi-aspirasi politik yang berbeda dari pemerintah yang didukung oleh gereja dan mengikuti gerakan-gerakan politik yang sikap dan pandangannya berlawanan dengan pemerintah maka secara teoritis gereja dan anggotanya berada dalam konflik. Tidak hanya itu, bahkan kalaupun anggotanya terlibat dalam aktivitas dan gerakan politik mendukung pemerintah, konflik ini tidak serta merta hilang begitu saja. Selama peraturan-peraturan yang diambil pemerintah adil dan benar, tunduk kepada pemerintah adalah pilihan yang wajar. Namun, ketika langkah yang diambil pemerintah tidak tepat, mengoyakkan keadilan dan merugikan orang-orang yang lemah, sikap patuh pada pemerintah menjadi pilihan yang sama sulitnya. Haruskah kepatuhan berjalan seperti biasa sementara sebagian anggota gereja dan orang-orang di luar gereja menjadi korban dari kebijakan pemerintah yang tidak adil? Dengan menyatakan diri patuh pada pemerintah, GKT berhasil menghindarkan diri dari konflik melawan pemerintah namun membuka medan konflik dengan anggota-anggota sendiri.

\section{NETRALITAS DAN SIKAP TERHADAP POLITIK}

Jika posisi GKT coba dianalisis lebih dalam, apa yang mau dicapai dari keputusan itu tampaknya adalah sterilitas gereja dari aktivitas politik praktis di mana gereja malih rupa menjadi partai atau gerakan politik yang berjuang untuk memperoleh kekuasaan (power). Setidaknya, 
sebagai sebuah perhimpunan orang dan sebagai sebuah lembaga yang punya tujuan-tujuan yang bersifat keagamaan, gereja harus netral dan tidak berpihak kepada kepentingan-kepentingan kelompok-kelompok politik tertentu. Kalaupun pada akhirnya ada yang harus dipihaki maka itu adalah pemerintah — " patuh kepada peraturan pemerintah."

Netralitas adalah isu yang timbul sejak Era Pencerahan (Enlightenment), dan secara khusus dihubungkan dengan sikap negara terhadap agama. Sikap ini dilatarbelakangi oleh aliansi kemitraan di antara gereja dan negara yang sudah berlangsung selama lebih dari seribu tahun sejak agama Kristen ditetapkan sebagai satu-satunya agama resmi negara oleh Kaisar Theodosius tahun 380. Dalam kemitraan ini, gereja mendukung pemerintah negara sementara pemerintah mendukung tumbuh-kembang gereja dan menjamin bahwa hanya boleh ada satu versi agama Kristen saja yang hidup dalam negara. Apa yang berbeda dari itu dipandang bidah dan harus disingkirkan sampai dihapuskan. ${ }^{3}$ Penghapusan bidah bukan saja baik untuk gereja namun juga baik untuk negara karena versi Kristen yang bermacam-macam akan mengganggu stabilitas negara. Dalam perkembangan selanjutnya, keduanya, negara dan gereja, raja dan imam, bahkan memahami bahwa mereka sebenarnya adalah bagian yang utuh dari satu badan yang sama. ${ }^{4}$ Akibatnya, negara tidak dapat mentolerir adanya pluralisme agama dan pluralitas agama Kristen. Gereja didukung secara finansial dan dilindungi dari perpecahan. Gereja membalasnya dengan mendukung kedaulatan penuh negara dan pemerintah atas warganya.

Konsep negara netral pada dasarnya berupaya memisahkan negara dari gereja dan sebaliknya supaya negara dan pemerintahnya dapat mengayomi seluruh warga negaranya dengan adil. Dalam pengertiannya yang paling sederhana, negara dan pemerintahan yang netral adalah yang berurusan tanpa pandang bulu dengan warganya dan tetap bersikap netral

\footnotetext{
3 Jonathan A. Wright, Separation of Church and State (California, CA.: Greenwood, 2010), p.viii.

${ }^{4}$ Ibid.,p.3.
} 
dengan keyakinan dan cara hidup yang dijalani oleh warganya. ${ }^{5}$ Konsepsi ini merupakan karakteristik utama dari sistem negara liberal, yang memilih tidak memaksakan suatu konsep apapun mengenai kebaikan kepada warganegaranya namun yang mengizinkan mereka mengejar kebaikannya sendiri menurut caranya masing-masing. ${ }^{6}$

Kalau negara diharapkan berbuat demikian maka gereja pun juga diharapkan berbuat sama kepada negara. Sama seperti negara dan pemerintah tidak lagi memaksakan keyakinan agama tertentu kepada warganya maka gereja juga tidak perlu lagi mempengaruhi negara apalagi memaksanya untuk menaruh preferensi khusus kepada gereja. Benihbenih pikiran ini sebenarnya sudah muncul pada Martin Luther dalam doktrin dua kerajaan - Kerajaan Allah dan Kerajaan Dunia. Dalam doktrin ini Luther memisahkan dua pemerintahan, yang ia namakan pemerintahan spiritual dan pemerintahan sekuler. Pemerintahan spiritual menolong manusia untuk mencapai kebenaran sejati dan hidup kekal; sementara pemerintahan sekuler melestarikan kehidupan jasmaniah dan temporer di dalam dunia ini. ${ }^{7}$ Pemerintahan tidak saja mencakup semua otoritas politis dan pemerintahan tetapi juga segala sesuatu yang berkontribusi kepada pelestarian hidup di dunia ini. ${ }^{8}$ Meski keduanya tidak bisa dipisahkan karena sama-sama merupakan "God's two modes of rule" namun kedua pemerintahan ini berbeda satu dari yang lain. ${ }^{9}$ Yang satu mengurus hal-hal batiniah, sementara yang lain lahiriah. Yang satu berbasis pada kemerdekaan dari dosa dan kuasa si jahat, yang lain berbasis pada hukum dan paksaan. ${ }^{10}$

${ }^{5}$ John T. S. Madeley, "European Liberal Democracy and the Principle of State Religious Neutrality," Church and State in Contemporary Europe: The Chimera of Neutrality, John T.S. Madeley \& Zsolt Enyedi, eds. (London: Frank Cass Publishers, 2003), p.4.

${ }^{6}$ Ibid.

${ }^{7}$ Paul Althaus, The Ethics of Martin Luther Dalam http://www.lutheransonline.net/lo/424/FSLO-1330611424-111424.pdf. (diakses pada 28 Juni 2015).

${ }^{8}$ Ibid.

9 Dr. John R. Stephenson, The Two Governments and the Two Kingdoms in Luther's Thought dalam http://www.lcms.org/Document.fdoc?src=lcm\&id=665. (diakses pada 28 Juni 2015).

${ }^{10}$ Richard V. Pierard, "The Lutheran Two Kingdoms Doctrine and Subservience to the State in Modern Germany" dalam Journal of the Evangelical Theological Society 29/2 (June 1986): p.194. 
Pembedaan inilah yang oleh proses zaman dari mulai konflik antar negara Kristen dalam perang tiga puluh tahun di Eropa pada abad ke-17, lalu Revolusi Prancis pada abad ke-18 dan perkembangan pemikiran humanisme pada masa Pencerahan kemudian dimutlakkan dan dipisahkan secara tegas. Sebagai reaksi terhadap kekacauan yang timbul dari Revolusi Prancis, sejumlah pemikir Kristen abad ke-19 awal yang prihatin pada masalah lemahnya otoritas negara dan kurangnya ketertiban mereinterpretasi gagasan Luther tentang dua kerajaan lalu sampai pada kesimpulan yang menekankan pentingnya negara sebagai penjaga ketertiban umum. Peran negara dalam ruang publik makin dikuatkan sementara peran agama (dan gereja) makin didesak ke dalam ruang batin manusia. ${ }^{11}$ Teologi ini bertemu dengan filosofi para pemikir humanisliberal yang tertarik pada ide otonomi institusi-institusi sosial dan tatanan alam. Berangkat dari keyakinan bahwa proses-proses sosial yang terjadi di zamannya ditentukan oleh hukum-hukum ilahi yang sudah baku mereka memandang tidak ada perlunya sama sekali bagi yang sekuler dan yang spiritual untuk saling bermitra. Yang sekuler dapat beroperasi secara otonom tanpa perlu bantuan yang spiritual. Akibatnya, iman, agama, gereja dikeluarkan dari ruang publik dan menjadi urusan privat tiap-tiap orang. Ia tidak ada kena-mengenanya dengan urusan sekuler. Maka keterlibatan gereja dalam politik adalah tabu; bahkan "the right to issue prophetic message" - hak untuk menyuarakan pesan kenabian kepada negarapun tidak ada. ${ }^{12}$ Dalam urusan-urusan fisik, jasmaniah dan lahiriah orang Kristen dan gereja harus tunduk dan patuh pada negara dan pemerintah.

Menurut para penafsirnya, Luther sebenarnya tidak pernah bermaksud sampai sejauh itu. Baik pemerintahan spiritual maupun pemerintahan sekuler adalah sama pentingnya. Keduanya memang berbeda namun tidak bertentangan. Keduanya memiliki area masingmasing namun keduanya saling melengkapi dan berkaitan. Lewat kesaksiannya akan kebenaran (truth) dan yang benar (right), gereja menolong bukan saja individu-individu masyarakat tetapi juga institusi-

\footnotetext{
${ }^{11}$ Pierard dalam Journal of the Evangelical Theological Society 29/2 (June 1986):p.195.

12 Ibid.,pp.195,196.
} 
institusi yang dibangun oleh individu-individu itu, yang terus-menerus di bawah ancaman pengaruh dosa. Karena itu baik orang maupun lembaganya terus membutuhkan kritik, penilaian dan sekaligus peningkatan supaya kebaikan untuk sesama manusia dapat diwujudkan. ${ }^{13}$

Dalam arti yang semacam ini, gereja sesungguhnya tidak bisa tinggal sebagai lembaga yang secara politis netral dan steril dari politik. Kalau netralitas dimaknai sebagai tidak partisan maka ide itu masih bisa diterima. Namun kalau netralitas juga dimasukkan makna tidak mau masuk ke dalam urusan politik negara, dalam urusan bagaimana negara dan pemerintah memperlakukan warga negaranya, maka hal itu tidak bisa diterima. Gereja punya tanggung jawab untuk mengingatkan negara dan pemerintah, sesama rekannya di bawah pemerintahan Allah, tentang apa yang seharusnya dilakukan dan bagaimana melakukannya dengan caracara adil, yang tidak saja membawa kebaikan bagi semua orang dalam negara namun juga akan memperkuat negara itu sendiri. Mengingatkan, mengkritik, mengevaluasi dan memberikan proposal untuk peningkatan akhirnya membawa gereja dalam artian tertentu untuk berpolitik.

\section{MAKNA POLITIK DAN SIKAP TERHADAP POLITIK}

Sikap yang diambil GKT sejak tahun 1969 itu tampaknya mengarah kepada jenis politik yang dikenal dalam percakapan populer masa kini sebagai politik praktis. Istilah ini sebenarnya tidak ada dalam kamus, setidaknya dalam edisi ketiga Kamus Besar Bahasa Indonesia. Istilah yang lebih umum adalah real politik, yang menunjuk kepada politik yang dibangun berdasarkan kepentingan praktis atau yang berbasis pada kekuasaan. Sasaran yang hendak dicapai adalah tercapainya kepentingan pribadi, kelompok, golongan atau negara, dan mendapatkan kekuasaan.

Namun politik, seperti yang dipahami secara ilmiah, tidak melulu bermakna seperti itu. Selain politik praktis masih ada politik yang

13 Pierard dalam Journal of the Evangelical Theological Society 29/2 (June 1986): pp.194-195. 
berbasis moral dan ideologi. Dalam artinya yang paling dasar, politik sesungguhnya adalah soal bagaimana membawa kebaikan bagi komunitas dalam mana berpolitik dilakukan. Dalam tulisannya yang berjudul Politics, Aristoteles berpendapat bahwa negara adalah sebuah komunitas, yang didirikan dan ditegakkan untuk mencapai suatu kebaikan bagi semua warganya. ${ }^{14}$ Untuk sampai ke sama dibutuhkan politik, yang merupakan seni untuk mengendalikan sekaligus mempertemukan kepentingan-kepentingan yang berbeda dalam negara. ${ }^{15}$ Dengan politik setiap konflik kepentingan tidak lagi diselesaikan dengan kekerasaan dan kekuasaan melainkan dengan dengan kata-kata dan persuasi. ${ }^{16}$ Politik, dalam maknanya yang seperti ini, adalah keharusan agar terjamin kelangsungan hidup yang baik dan manusia terhindar dari kekerasan yang menghancurkan dirinya. ${ }^{17}$

Sampai pertengahan abad kedua puluh, semua orang yang mendapat kebaikan oleh politik tidak mendapat kualifikasi khusus. Oleh pengaruh filsafat utilitarianisme, semua orang dipahami sebagai sebagian besar orang atau mayoritas orang di dalam negara. Politik bermaksud membawa kebaikan untuk kaum mayoritas itu. Kaum minoritas-apakah itu yang berdasarkan etnis, agama, bahasa, daerah dan lain-lain - tidak diperhatikan. Jika dalam proses politik mereka mengalami kekerasan dan penindasan, selama hal itu mendatangkan kebaikan untuk bagian terbesar masyarakat maka politik yang semacam itu dipandang baik. Logika utilitarian yang mendominasi filsafat dan praktik politik sejak berabadabad lamanya ini, kemudian mendapat tantangan serius dari John Rawls dengan teorinya mengenai keadilan. ${ }^{18}$

\footnotetext{
${ }^{14}$ Lihat Aristotle, Politics, terj. H. Rackham, M.A. (London: William Heinemann Ltd, 1959), h.3.

15 Roger Scruton, Palgrave Macmillan Dictionary of Political Thought (New York: Macmillan, 2007), p.535.

${ }^{16}$ Hannah Arendt, The Human Condition (Chicago, IL.: The University of Chicago Press, 1998), p.26.

${ }^{17}$ Frank Bealey, The Blackwell Dictionary of Political Science (Oxford, UK.: Blackwell, 1999), p.261.

18 Uraian ringkas tentang teori Rawls dan tinjauan atasnya lihat Henry S. Richardson, “John Rawls (1921-2002)", http://www.iep.utm.edu/rawls/print (diakses pada 27 Juni 2015).
} 
Kalau negara, seperti diteorikan Rousseau, sejatinya adalah sebuah kontrak antar warga negara maka tiap warga negara sudah seharusnya mendapatkan perlakuan yang adil dari negara. Yang satu tidak boleh dikecualikan dari yang lain; dan yang lain tidak boleh dikorbankan demi kebaikan yang lain lagi. Dasar berpikir Rawls adalah bahwa setiap orang memiliki suatu kualitas yang dibangun di atas keadilan, yang tidak bisa dilanggar, dirampas atau dibatalkan oleh siapa pun bahkan demi kesejahteraan seluruh masyarakat sekalipun. ${ }^{19}$ Keadilan menuntut bahwa hak-hak tiap orang dipenuhi oleh negara dan tidak ditundukkan "pada tawar-menawar politik atau kalkulasi kepentingan sosial."20 Dari sini tujuan politik bukan lagi untuk mewujudkan kebaikan yang dirasakan oleh mayoritas melainkan harus dirasakan oleh tiap warga negara tanpa pandang bulu. Dalam perahu kebaikan bersama, setiap orang harus mendapat tempatnya. Politik yang baik memastikan bahwa tak ada seorang pun yang tertinggal.

Dalam tataran makna politik yang semacam ini gereja mau tidak mau harus terlibat dalam politik. Jika cinta kasih, yang menjadi karakteristik gereja, benar-benar dipraktekkan maka perbuatan kasih yang dilakukan kepada sesama juga harus melibatkan usaha dan tindakan yang memastikan bahwa sesama mendapatkan kebaikan dan keadilan yang menjadi haknya sebagai warga negara. Tugas terakhir ini tidak bisa dilakukan sendirian oleh anggota-anggota gereja. Institusi-institusi politik yang menjadi kendaraan orang dalam berpolitik bukanlah lembaga yang bebas dari kepentingan. Lembaga-lembaga politik itu juga punya agenda dan kepentingan politiknya sendiri. Setelah berada di dalamnya visi dan pandangan pribadi diselaraskan dengan tujuan dan kepentingan pragmatis partai politik. Di sinilah anggota-anggota gereja tidak bisa berbuat seleluasa seperti yang dibayangkan.

Sebagai lembaga yang berdiri bukan untuk mengejar kekuasaan atau kepentingan politis dan ekonomis tertentu, gereja dapat berbuat

\footnotetext{
${ }^{19}$ John Rawls, A Theory of Justice, revised edition(Cambridge, MA.: The Belknap Press, 1999), p.3.

20 John Rawls, Teori Keadilan: Dasar-dasar Filsafat Politik untuk Mewujudkan Kesejahteraan Sosial dalam Negara (Yogyakarta: Pustaka Pelajar, 2006), h.4.
} 
sesuatu secara lebih leluasa. Dituntun oleh visi alkitabiah tentang masyarakat dan cara-cara berpolitik yang sehat, gereja dapat berkontribusi dalam membangun negara dan pemerintahan yang lebih baik lewat kritik, evaluasi dan tawaran konsep yang lebih baik. Cinta kasih yang sejati kepada sesama mau tidak mau akan membawa gereja melangkah sampai sejauh ini.

\section{PEMERINTAHAN DAN SIKAP TERHADAP POLITIK}

Pemerintahan macam apa yang dapat membawa kebaikan bagi seluruh warga negara tanpa pandang bulu? Di sini para filsuf politik terbagi ke dalam dua kubu. Kubu pertama, yang diwakili oleh para filsuf Yunani klasik dan Romawi serta pemikir-pemikir Kristen abad pertengahan, berpendapat bahwa politik semacam itu hanya dapat dijalankan oleh penguasa yang bermoral. Namun bersamaan dengan munculnya Renaissance, pemikiran klasik itu mulai digantikan oleh pendapat kubu kedua yang memandang bahwa moralitas bukan kriteria yang penting bagi pemimpin. Demi kebaikan yang lebih besar bagi komunitas politis, negara dan representasi-representasinya dapat dan harus bertindak di luar kerangka moral yang dikenakan pada orang-orang biasa. $^{21}$ Atas nama kebaikan bersama, pemerintah boleh dan harus berlaku otoriter - diktatorial, bahkan kalau perlu menjadi seorang tiran penguasa yang lalim dan sewenang-wenang. ${ }^{22}$

Alasan kenapa harus demikian adalah karena manusia, seperti yang digambarkan oleh Thomas Hobbes, salah seorang penyokong gagasan ini, adalah makhluk yang berkodrat mudah sesat dalam upayanya mencari pengetahuan, rapuh kapasitasnya untuk bernalar dan mengetahui, cenderung berbuat salah dan kena pengaruh yang tidak semestinya. Bila

${ }^{21}$ Frederic Volpi, "Politics," The Cambridge Dictionary of Sociology, Bryan S. Turner, ed., (Cambridge, UK.: Cambridge University Press, 2006), p.445.

${ }^{22}$ Luther sendiri berpendapat bahwa kaisar atau raja tidak perlu adalah seorang suci atau bahkan seorang Kristen. Ia menasihati orang-orang Kristen yang hendak masuk dalam urusan mengelola pemerintahan untuk belajar dari kekayaan literatur kafir zaman kuno. Mereka "far more skilful than Christians in these matters." Lihat Stephenson, The Two Governments and the Two Kingdoms in Luther's Thought dalam http://www.lcms.org/Document.fdoc?src=lcm\&id=665. (diakses pada 28 Juni 2015) 
bertindak ia dapat begitu mementingkan dirinya sendiri, impulsif dan bodoh, sebagai hasil dari nalar yang keliru, teologi yang buruk atau karena terbawa oleh perasaan orang lain. ${ }^{23}$ Dengan kodrat yang semacam ini, Hobbes pesimis bahwa manusia akan dapat menemukan kebaikan dalam hidup bersama dengan orang lain. Yang akan terjadi adalah manusia hidup penuh kekerasan, di bawah ancaman terus-menerus dan merasa tidak aman.

Untuk keluar dari masalah itu manusia, menurut Hobbes, Machiavelli dan lain-lain, memerlukan seorang penguasa absolut, yang memerintah dengan tangan besi. Penguasa macam ini harus dibebaskan dari bertanggung jawab secara moral dan politis kepada orang-orang yang dipimpinnya. Di bawah kekuasaan seperti inilah maka segala kecenderungan jahat orang akan dapat dikontrol dan dikendalikan sehingga suatu kebaikan dapat dialami manusia dalam kehidupan bersama.

Gagasan ini bertahan cukup lama sampai kemudian disadari bahwa politik adalah urusan dan aktivitas untuk rakyat juga. Kesadaran ini mulai diperkenalkan oleh John Locke dan Montesquieu lalu disempurnakan oleh pikiran Rousseau dan Revolusi Perancis. ${ }^{24}$ Berbeda dari Hobbes, Locke memahami manusia secara positif sebagai makhluk yang setara dengan sesamanya, yang tidak boleh ditundukkan di kaki sesamanya dan terikat untuk melestarikan dirinya dan sesamanya. ${ }^{25}$ Tiap orang dilahirkan,

with a title to perfect freedom, and an uncontrouled enjoyment of all the rights and privileges of the law of nature, equally with any other man, or number of men in the world, hath by nature a power, not only to preserve his property, that is, his life, liberty and estate, against the injuries and attempts of other men; but to judge of, and punish the breaches of that law in others, as he is persuaded the

23 Lihat Garrath Williams, "Thomas Hobbes: Moral and Political Philosophy" dalam http://www.iep.utm.edu/hobmoral/print (diakses pada 27 Juni 2015).

${ }^{24}$ Volpi dalam Turner, ed., The Cambridge Dictionary of Sociology, p.446.

25 John Locke, Second Treatise of Government (Indianapolis, IN.: Hackett Publishing Company, Inc., 1980), p. 9. 
offence deserves, even with death itself, in crimes where the heinouseness of the fact, in his opinion, requires it. ${ }^{26}$

Dengan kodratnya yang semacam ini manusia tidak membutuhkan pemerintahan absolut yang berniat mengontrol dan mengendalikan kejahatan yang ada dalam dirinya. Yang dibutuhkannya adalah pemerintahan yang dapat menjadi wasit yang tidak berpihak, yang "restraint the partiality and violence of man," 27 yang terjadi dapat dalam perkara antar manusia. Dalam model ini soal bermoral atau tidak bukan prioritas. Yang lebih penting adalah apakah suatu pemerintahan kapabel dalam melaksanakan tugasnya itu atau tidak.

Kalau alasan orang bergabung dalam masyarakat seperti diteorikan Locke adalah utuk melestarikan propertinya ${ }^{28}$ maka tujuan yang mau dicapai oleh sebuah masyarakat, menurut Rousseau, adalah untuk "preservation and prosperity of its members." ${ }^{29}$ Maka pemerintahan yang baik, dalam pandangannya, adalah pemerintahan yang "without external aids, without naturalization or colonies" mampu membuat "the citizens increase and multiply most." $" 30$ Yang dipahami Rousseau adalah pertambahan jumlah penduduk dalam negara. Isu ini menjadi di tengah zaman di mana penyakit mudah sekali menyebar sementara ilmu pengobatan masih sangat tertinggal dan peperangan demi peperangan mudah sekali mereduksi jumlah penduduk suatu negara menjadi sangat kecil. Penduduk yang kurang berarti negara yang lemah.

Dalam diskusi masa kini, pemerintahan yang baik secara ringkas didefinisikan sebagai pemerintahan yang mampu memberikan layanan publik yang maksimal kepada rakyatnya. Dalam sebuah laporan yang disiapkan untuk badan audit nasional Inggris pada tahun 2008, Pricewaterhouse Coopers LLP memberikan sejumlah kriteria untuk pemerintahan yang baik. Yang pertama, pemerintahan yang baik adalah

\footnotetext{
${ }^{26}$ John Locke.Second Treatise of Government, p. 46.

${ }^{27}$ Ibid., p.12.

${ }^{28}$ Ibid., p. 111 .

29 Jean-Jacques Rousseau, On The Social Contract (Mineola, NY.: Dover Publications, Inc., 2003), p.57.

${ }^{30}$ Ibid.
} 
yang makin terdesentralisasi dan semakin dekat dengan warga negaranya. Yang kedua, pemerintahan yang baik itu akuntabel dan transparan. Dan terakhir, pemerintahan yang baik itu mempergunakan metode-metode manajemen dan praktek-praktek terbaik dari dunia industri untuk mendorong kinerja dan efisiensi di sektor publik. $^{31}$ Lebih lanjut, pemerintahan yang baik ditandai dengan sejumlah hal: dijalankan oleh orang-orang yang dengan keahlian dan keterampilan yang tepat, memakai struktur, sistem dan prosedur yang membuat pemerintahan berjalan dengan baik, dapat mempertanggungjawabkan kebijakan dan perundangan yang dibuat, mencapai dan mewujudkan tujuan-tujuan yang sudah ditetapkan serta menggunakan standar-standar etika yang tinggi dalam kehidupan publiknya. ${ }^{32}$

Dalam alinea keempat Pembukaan Undang-undang Dasar 1945 dinyatakan bahwa tujuan dibentuknya pemerintahan negara Indonesia adalah untuk " melindungi segenap bangsa Indonesia dan seluruh tumpah darah Indonesia dan untuk memajukan kesejahteraan umum, mencerdaskan kehidupan bangsa, dan ikut melaksanakan ketertiban dunia yang berdasarkan kemerdekaan, perdamaian abadi dan keadilan sosial." Pemerintahan yang baik adalah pemerintahan yang dapat memenuhi seluruh tujuan ini. Dalam teks UUD 45 sebelum amandemen, sama sekali tidak disebutkan suatu kriteria moral untuk menjadi pemimpin pemerintahan (presiden). Pemerintahan yang baik semata-mata diukur berdasarkan sejauh mana tujuan-tujuan negara diwujudkan. Pasca amandemen, suatu kriteria moral dirasa perlu untuk ditambahkan kepada syarat-syarat pemimpin pemerintahan (baca: presiden). Dalam Pasal 7A yang mengatur pemberhentian presiden dinyatakan bahwa presiden dapat diberhentikan jika terbukti melakukan pelanggaran moral seperti korupsi, penyuapan, tindak pidana dan perbuatan tercela. Maka pemerintahan yang baik tidak saja kapabel tapi juga harus bermoral baik.

31 Pricewaterhouse Coopers LLC, Commentary on International Models of Good Government: Prepared for the National Audit Office, September 2008: pp.8-9.

32 Public Administration Select Committee, Good Government: Eight Report of Session 2008-2009 (London, UK.: House of Commons, 2009), p.5. 
Sebagai bagian dari komponen masyarakat yang ambil bagian dalam kontrak sosial untuk mewujudkan hidup bersama yang baik, adil, makmur dan sejahtera untuk semua orang, gereja sesungguhnya tidak bisa benar-benar apolitis. Gereja juga punya tanggung jawab untuk memastikan dan sekaligus mengupayakan agar pemerintahan negara diurus oleh orang-orang yang kapabel untuk membawa keadilan dan kebaikan secara fair untuk semua orang. Dalam konteks negara Indonesia yang multi-agama dan multi-etis, ide bahwa sang pemimpin atau wakil rakyat harus seagama, segereja atau seetnis tentu bukan keharusan karena hal itu sama sekali tidak ada hubungannya dengan kapabilitas seseorang atau suatu pemerintahan. Ukuran yang sebaiknya dipergunakan adalah kemampuan mengelola negara dan pemerintahan serta karakter moralnya.

Apakah ini berarti bahwa gereja sebagai lembaga dapat memberikan dukungan resmi kepada seseorang atau kelompok tertentu yang bercita-cita untuk mengelola negara? Sebagian besar orang Kristen mengatakan hal itu sebaiknya tidak dilakukan. Itu bukan bagian dari tugas pastoral gereja. Gereja sebaiknya harus netral. Salah satu masalah yang hendak dihindari oleh posisi ini adalah risiko yang akan dihadapi gereja dari pihak luar dan pihak dalam gereja. Jika orang atau kelompok orang yang didukungnya kalah dalam kontes maka gereja akan diselamatkan dari kerugian sosial dan politis yang dapat disebabkan oleh kemarahan atau ketersinggungan pihak yang menang yang tidak didukung gereja. Kalaupun hal ini tidak terjadi, setidaknya gereja selamat dari rasa malu karena salah membaca " kehendak Tuhan.” Secara internal gereja diselamatkan dari rasa tidak senang anggotanya sendiri yang merasa tidak didukung oleh gerejanya. Tapi apakah semuanya ini benarbenar tepat menurut ukuran-ukuran etis Kristen? Apakah sikap tidak jelas mendukung siapa adalah sebuah pilihan yang bertanggung jawab?

Kalau cara berpikir Luther dipakai maka gereja, sebagai pemerintahan spiritual, harus betul-betul berupaya supaya mitranya dalam "preserve the fallen Creation and to prevent sinful man from tearing God's world apart" betul-betul diisi oleh orang-orang yang akan melaksanakan tanggung jawab ini dengan baik. Membicarakan calon 
mitra itu dalam bahasa yang impersonal sebagai “ tidak korup, bersih dan peduli pada rakyat" malah akan menjadi tidak bertanggung jawab kalau hal itu tidak dibarengi dengan suatu paparan yang dibangun di atas data dan fakta tentang orang-orang yang mencalonkan dirinya sebagai pemimpin. Sebagai lembaga gereja tentu tidak punya hak pilih dan tidak juga bisa memaksa anggotanya untuk memilih. Namun gereja bisa berbuat sesuatu yang lebih dari sekedar pesan pastoral yang kabur itu. Dengan sumber daya yang dimilikinya gereja dapat melakukan investigasi dan penelitian mendalam atas calon-calon pemimpin negara, kota, lokal dan nasional. Hasil penelitian ini kemudian dibeberkan kepada anggota-anggotanya untuk menolong mereka memiliki calon-calon pemimpin yang tepat. Aktivitas politik sejauh ini patut untuk dilakukan gereja, apalagi di tengah-tengah minimnya pemahaman dan pengertian warga gereja tentang calon-calon pemimpinnya serta kuatnya aroma politik uang dan pencitraan via media. Tentu saja hal ini juga harus dibarengi dengan kesiapan untuk menyampaikan pesan kenabian kepada pemimpin yang terpilih. Ini adalah tanggung jawab yang melekat pada seorang mitra kepada mitranya dalam sebuah pekerjaan ilahi yang sama.

\section{KEBERDOSAAN PEMERINTAH DAN SIKAP TERHADAP POLITIK}

Kesediaan dan kesiapan untuk memberi kritik dan evaluasi sekaligus menyodorkan gagasan yang lebih baik kepada pemerintah perlu ada karena hakikat negara dan pemerintah menuntutnya demikian. Dalam teori-teori politik modern, ada suatu bangun teori yang melihat negara (state) sebagai realitas yang terpisah dari masyarakat (society). Jikalau politik, seperti dipahami Volpi sebagai "mengendalikan dan mengarahkan seluruh kekuatan sosial dari suatu masyarakat menjadi sebuah organisasi yang efektif" ${ }^{33}$ maka negara, menurut bangun teori tersebut adalah salah satu kekuatan sosial di dalam masyarakat juga. ${ }^{34}$

\footnotetext{
${ }^{33}$ Volpi dalam Turner, ed., The Cambridge Dictionary of Sociology, p.445.

${ }^{34}$ Selengkapnya lihat Joel S. Migdal, State in Society: Studying How States and Societies Transform and Constitute One Another (New York: Cambridge University Press, 2004). Juga Joel S. Migdal, Atul Kohli \& Vivienne Shue, eds. State Power and Social Forces:
} 
Perbedaannya adalah dibandingkan dengan kekuatan-kekuatan sosial lain dalam masyarakat, negara memiliki satu kelebihan yaitu kuasa untuk mengatur yang lain serta hak istimewa untuk mempergunakan kekuatan (force) dalam mengancam dan memaksa yang lain menuruti kemauannya. Kekuatan dan paksaan merupakan sarana yang secara spesifik melekat pada negara. ${ }^{35}$ Dengan alat itu maka pemerintah dapat memaksakan agenda-agenda dan kepentingan-kepentingannya kepada rakyat.

Pemaksaan ini menjadi sangat penting dalam negara-negara berkembang seperti Indonesia pada zaman Orde Baru di mana kepentingan negara menjadi sesuatu yang dibela mati-matian. Apalagi ketika tatanan negara sebelumnya dipandang telah menyimpang dari citacita awal negara maka dominasi atas kehidupan warga negara menjadi sesuatu yang pasti. Namun terlepas dari maksud-maksud baik yang ingin dicapai, pemerintah bukanlah aktor-aktor yang netral, yang bersih dari kepentingan yang lain. Hak istimewa untuk memaksa warga negara dengan kekuatan yang dimiliki dapat menyimpang dari maksud dan tujuan yang baik dan berujung kepada bencana. Itu sebabnya dukungan dan apalagi kepatuhan kepada pemerintah tidak bisa tanpa batas dan syarat.

Adalah Reinhold Niebuhr yang mengingatkan orang-orang Kristen untuk menyadari bahwa bangsa, negara dan pemerintah bukanlah aktoraktor yang inosen. Mereka juga punya agenda dan kepentingan sendiri egoismenya sendiri. ${ }^{36}$ Kepentingan atau egoisme ini ditampilkan, misalnya, dalam memanggil warga negara untuk berkorban bagi bangsa dan negara padahal sesungguhnya yang diperjuangkan adalah kepentingan elit tertentu atau oknum-oknum tertentu, atau demi menjaga citra baik pemerintahan atau untuk mempertahankan kelangsungan kekuasaan. Niebuhr secara khusus menyebut masalah "hipocrisy" —

Domination and Transformation in the Third World (New York: Cambridge University Press, 1997).

35 Max Weber, The Vocation Lectures: "Science as a Vocation" and "Politics as a Vocation" (Indianapolis, IN.: Hackett Publishing Company Inc., 2004), p.33.

${ }^{36}$ Lihat misalnya Reinhold Niebuhr, Moral Man and Immoral Society (New York: Charles Scribner's Sons, 1932), Bab IV-V. 
kemunafikan - sebagai problem moral bangsa dan pemerintahannya. ${ }^{37}$ Problem ini khususnya menonjol ketika negara, oleh pemerintahnya, dikesankan dalam kondisi gawat. Penangkapan tokoh-tokoh tertentu atau penindasan kelompok-kelompok minoritas dilakukan dengan alasan, misalnya, demi keamanan dan stabilitas negara. Sementara di sisi lain, pemerintah menyampaikan menjunjung tinggi hak-hak asasi manusia. Penerimaan masyarakat terhadap ketidakadilan di satu pihak dan kebanggaan di pihak lain atas komitmen pemerintah pada hak-hak asasi manusia, oleh Neibuhr, tidak mungkin dapat terjadi tanpa ketidakjujuran.

Niebuhr sampai kepada gagasan-gagasannya karena ia menyadari bahwa dosa begitu kuat mencengkeram hidup manusia, tidak saja di level personal namun juga di level sosial dan nasional. ${ }^{38}$ Menulis di tengah zaman yang didominasi oleh dua ideologi besar, yaitu Liberalisme dan Marxisme, yang sama-sama punya problem dalam konsep dosa dan penebusan dari dosa. Niebuhr mengkritik kekristenan liberal yang memandang "the Christian idea of sinfulness of all men was outmoded" dan mengkritik Marxisme yang menawarkan "redemption through the death of an old order and the rise of a new one" bukan "redemption through the perpetual dying to self of the Christian Gospel." 39 Namun ia juga mengkritik sejumlah sikap gereja terhadap tatanan politik nasional sebagai sikap yang tidak sepantasnya diambil. Sebagian gereja berpikir bahwa masalah politik adalah soal yang tidak relevan dengan hidup Kristen. Kepada gereja yang coba bersikap netral ia mengatakan bahwa "this neutrality has not even been honestly neutral. The neutral Church is usually an ally of the established social forces." 40 Gereja lain, karena bingung dan takutnya kepada kompleksitas dunia politik, lantas memilih hidup dengan perasaan susah tak tertahankan karena manusia hidup tidak

\footnotetext{
${ }^{37}$ Reinhold Niebuhr, Moral Man and Immoral Society, pp.95-110.

${ }^{38}$ Dalam hal ini Niebuhr dan kaum Kristen realis berhutang pada Agustinus. Lihat Eric Patterson, "Christianity and Power Politics: Themes and Issues", Christianity and Power Politics Today: Christian Realism and Contemporary Political Dilemmas, Eric Patterson, ed. (New York: Palgrave Macmillan, 2008), p.4.

39 Reinhold Niebuhr, Christian Realism and Political Order (New York: Charles Scribner's Sons, 1935), pp.106-107.

${ }^{40}$ Ibid.,p.109.
} 
saling mengasihi. ${ }^{41}$ Yang dibutuhkan manusia adalah hukum kasih dan sebuah "tolerable community"-komunitas yang toleran. Masalah dengan gagasan ini adalah hal itu tidak bisa diwujudkan, bahkan di dalam gereja sendiri, karena "all men, including Christians, are inclined to take advantage of each other." 42 Gereja lain coba menyelesaikan kerumitan masalah hidup masyarakat dengan mengangkat isu keadilan dan undangundang yang detil untuk mengatur kehidupan sosial dan politik manusia. Yang tidak benar-benar disadari oleh gereja yang mengajukan proposal itu adalah bahwa semua hukum dan undang-undang mudah sekali berubah menjadi instrumen dosa dan keadilan yang tidak fleksibel malah justru jadi penghambat terwujudnya keadilan yang sejati. ${ }^{43}$

Cara-cara yang pada ujungnya hanya untuk menyelamatkan diri sendiri dan tidak mau merepotkan diri dalam persoalan hidup bersama orang lain ini ditolak Niebuhr. Ia menduga bahwa di balik sikap-sikap itu ada asumsi yang memandang pemerintah dan institusi-institusinya sebagai sesuatu yang sakral dan tidak boleh dijamah. Niebuhr menolaknya. Negara, bangsa, pemerintah dan institusi-institusinya juga tunduk kepada korupsi. Namun juga harus diingat bahwa upaya-upaya untuk menghapuskannya - seperti diupayakan oleh Marxisme - pun tunduk pada korupsi yang sama. ${ }^{44}$ Dosa dan maut yang menguasai individu juga mempengaruhi bangsa sebagai "the collective life of mankind" " yakni negara, bangsa, masyarakat dan pemerintahnya. Maka kewajiban gereja adalah:

to mediate the divine judgment and grace that nations, classes, states and cultures, as well as individuals, may discern the divine author of their wounds, that they may also know the possibility of a new and whole life. In a day of complacency and security the Christian Church must anticipate the judgment which is to come and declare that the day of the Lord will be darkness and not light.

\footnotetext{
${ }^{41}$ Niebuhr, Christian Realism and Political Order, p.109

${ }^{42}$ Ibid.,pp.109-110.

${ }^{43}$ Ibid.,p. 110.

${ }^{44}$ Ibid.,pp.110-111.

${ }^{45}$ Ibid. p. 111 .
} 
In the day of judgment and catastrophe the Christian Gospel has a message of hope for those who truly repent. ${ }^{46}$

Dengan kata lain, gereja tidak bisa tinggal diam. Gereja punya tanggung jawab terhadap "the health of our communities, our nations and our culture." Gereja yang lari dari tanggung jawab itu akan merosot menjadi "an intolerable other-worldliness." 47

\section{PENUTUP}

Merenungkan alasan kenapa gereja-gereja berlatar belakang Tionghoa lebih banyak bersikap apolitik, Mungki A. Sasmita menemukan ada tiga penyebab. Yang pertama adalah karena pandangan teologis tentang politik yang diwarisi dari kaum pietis Eropa dan para pengabar Injil pietis dari Tiongkok, yang menekankan kebangunan dan kehidupan rohani individu. Yang kedua karena pengalaman sebagai kaum minoritas ganda (Tionghoa dan Kristen), yang penuh trauma, khususnya sejak tahun 1965. Dan terakhir, karena budaya konfusianisme yang punya kecenderungan apolitis. Sebagai pebisnis, orang-orang Tionghoa merasa perlu menjaga relasi baik dengan penguasa supaya bisnis tetap lancar dan aman dari gangguan. ${ }^{48}$ Sampai sejauh mana tiga sebab ini ada di GKT tentu masih perlu dibuktikan oleh penelitian yang lebih mendalam.

\footnotetext{
${ }^{46}$ Niebuhr, Christian Realism and Political Order,112. Terjemahannya: "untuk menyampaikan penghakiman dan anugerah Allah supaya bangsa-bangsa, kelas-kelas, negara-negara dan kebudayaan-kebudayaan juga individu-individu mengenali penyebab ilahi dari luka-luka mereka, sehingga mereka dapat mengenali kemungkinan hidup yang benar-benar baru. Pada masa kenyamanan dan rasa aman Gereja Kristen harus mengantisipasi apa yang akan tiba dan mengumumkan hari Tuhan akan menjadi gelap dan bukan terang. Pada hari penghukuman dan bencana Injil Kristen menawarkan pesan pengharapan bagi mereka yang sungguh-sungguh bertobat."

47 Ibid., 116. Sudah dimaklumi dalam dunia sosiologi agama bahwa agama adalah institusi yang mengurus soal-soal dunia lain. Namun gereja, dalam pandangan Niebuhr, akan jatuh menjadi lembaga yang tidak dapat ditoleransi lagi ketika ia hanya mengurus dunia lain dan tidak peduli pada politik yang menjadi bagian dari kehidupan gereja di dalam dunia ini.

48 Mungki A. Sasmita, "Gereja dan Politik”, makalah untuk Forum Pembinaan Majelis Jemaat GKI Klasis Semarang Barat dan Semarang Timur, 20 Januari 2009. Link http://sulutiptek.com/documents/MAKALAH-GEREJADANPOLITIK.doc.pdf. (diakses pada 30 Juni 2015).
} 
Namun sikap terhadap politik yang diambil pada akhir dekade 60 -an itu sudah waktunya untuk ditinjau kembali.

Argumen-argumen yang coba disodorkan dalam tulisan ini hendak mendorong terjadinya sebuah tinjau ulang sikap gereja terhadap politik di Indonesia pada masa kini, agar gereja, secara khusus lagi GKT dapat berkontribusi secara maksimal dalam kehidupan berbangsa dan bermasyarakat. Proposal-proposal yang disajikan bukan kata akhir. Diperlukan diskusi yang lebih banyak dan konstruktif. Catatannya adalah sikap yang kemudian diambil harus mempertimbangkan dengan sangat serius makna politik dan pemerintah seluas-luasnya dan panggilan gereja dalam area politik. Akhirnya, sikap apapun yang kemudian diambil, gereja sepatutnya memilih untuk menaruh rasa amannya dalam tangan Tuhan, bukan dalam kuasa dan siasat manusia.

\section{DAFTAR RUJUKAN}

Althaus, Paul. The Ethics of Martin Luther dalam http://www.lutheransonline.net/lo/424/FSLO-1330611424111424.pdf. (diakses pada 28 Juni 2015).

Arendt, Hannah. The Human Condition. Chicago, IL.: The University of Chicago Press, 1998.

Aristotle. Politics. London: William Heinemann Ltd, 1959.

Bealey, Frank. The Blackwell Dictionary of Political Science. Oxford, UK.: Blackwell, 1999.

Locke, John. Second Treatise of Government. Indianapolis, IN.: Hackett Publishing Company, Inc., 1980.

Madeley, John T.S. "European Liberal Democracy and the Principle of State Religious Neutrality," Church and State in Contemporary Europe: The Chimera of Neutrality, John T.S. Madeley \& Zsolt Enyedi, eds. London: Frank Cass Publishers, 2003. 
Migdal, Joel S. State in Society: Studying How States and Societies Transform and Constitute One Another. New York: Cambridge University Press, 2004.

Migdal, Joel S., Atul Kohli \& Vivienne Shue, eds. State Power and Social Forces: Domination and Transformation in the Third World. New York: Cambridge University Press, 1997.

Niebuhr, Reinhold. Moral Man and Immoral Society. New York: Charles Scribner's Sons, 1932.

Niebuhr, Reinhold. Christian Realism and Political Order. New York: Charles Scribner's Sons, 1935.

Patterson, Eric. "Christianity and Power Politics: Themes and Issues", Christianity and Power Politics Today: Christian Realism and Contemporary Political Dilemmas, Eric Patterson, ed. New York: Palgrave Macmillan, 2008.

Pierard, Richard V. "The Lutheran Two Kingdoms Doctrine and Subservience to the State in Modern Germany," Journal of the Evangelical Theological Society 29/2 (June 1986):193-203.

Pricewaterhouse Coopers LLC. Commentary on International Models of Good Government: Prepared for the National Audit Office, September 2008.

Public Administration Select Committee. Good Government: Eight Report of Session 2008-2009. London, UK.: House of Commons, 2009.

Rawls, John. A Theory of Justice, revised editio.Cambridge, MA.: The Belknap Press, 1999.

Rawls, John. Teori Keadilan: Dasar-dasar Filsafat Politik untuk Mewujudkan Kesejahteraan Sosial dalam Negara. Yogyakarta: Pustaka Pelajar, 2006.

Richardson, Henry S. "John Rawls (1921-2002)", http://www.iep.utm.edu/rawls/print (diakses pada 27 Juni 2015). 
Ringkasan Akta Sidang Lengkap Tahun 1969 Sinode Gereja Kristus Tuhan, Butir III.

Rousseau, Jean-Jacques. On The Social Contract (Mineola, NY.: Dover Publications, Inc., 2003.

Sasmita, Mungki A. "Gereja dan Politik", makalah untuk Forum Pembinaan Majelis Jemaat GKI Klasis Semarang Barat dan Semarang Timur, 20 Januari 2009. Link http://sulutiptek.com/documents/MAKALAH-

GEREJADANPOLITIK.doc.pdf. (diakses pada 30 Juni 2015).

"Selayang Pandang Kehidupan Oikumenis GKI Jatim," Buku Kenangkenangan 50th Gereja Kristen Indonesia Jawa Timur, 22-2-193422-2-1984. Malang: Panitia HUT Ke-50 Gereja Kristen Indonesia Jawa Timur, 1984.

Scruton, Roger. Palgrave Macmillan Dictionary of Political Thought. New York: Macmillan, 2007.

Stephenson, John R. The Two Governments and the Two Kingdoms in Luther's Thought dalam http://www.lcms.org/Document.fdoc?src=lcm\&id=665. (diakses pada 28 Juni 2015).

Volpi, Frederic. "Politics," The Cambridge Dictionary of Sociology, Bryan S. Turner, ed., The Cambridge Dictionary of Sociology. Cambridge, UK.: Cambridge University Press, 2006.

Weber, Max. The Vocation Lectures: "Science as a Vocation" and "Politics as a Vocation." Indianapolis, IN.: Hackett Publishing Company Inc., 2004.

Williams, Garrath. "Thomas Hobbes: Moral and Political Philosophy" dalam http://www.iep.utm.edu/hobmoral/print(diakses pada 27 Juni 2015).

Wright, Jonathan A. Separation of Church and State. California, CA.: Greenwood, 2010. 